https://helda.helsinki.fi

\title{
Tenure track career system as a strategic instrument for academic leaders
}

\section{Pietilä, Maria Susanna}

2015

Pietilä , M S 2015 , ' Tenure track career system as a strategic instrument for academic leaders ' , European Journal of Higher Education , vol. 5 , no. 4 , pp. 371-387 . https://doi.org/10.1080/21568235.201

http://hdl.handle.net/10138/234166

https://doi.org/10.1080/21568235.2015.1046466

acceptedVersion

Downloaded from Helda, University of Helsinki institutional repository.

This is an electronic reprint of the original article.

This reprint may differ from the original in pagination and typographic detail.

Please cite the original version. 


\title{
Tenure track career system as a strategic instrument for academic leaders
}

\author{
Maria Pietilä ${ }^{a^{*}}$ \\ ${ }^{a}$ Department of Political and Economic Studies, University of Helsinki, Finland
}

This is a final draft of the manuscript (Author's Accepted Manuscript).

The article has been published in European Journal of Higher Education (Taylor \& Francis), 2015, 5(4), 371-387.

DOI: $10.1080 / 21568235.2015 .1046466$.

The published article can be obtained at:

http://www.tandfonline.com/doi/abs/10.1080/21568235.2015.1046466?journalCode=rehe20

\begin{abstract}
This study examines the purposes for which leaders in universities use academic career systems. It focuses on the tenure track system which is new to Finland. Tenure track represents a newly established internal career path in a situation in which Finnish universities' organisational autonomy increased via new legislation from 2010. Drawing predominantly on interviews with academic leaders at two universities, the study investigates the goals of the career system. Shared aspirations include using the tenure track to attract high-performing junior researchers and to allocate resources within the university. The study's main focus is on governance structures: it examines the extent to which internal career paths contribute to making Finnish universities organisational actors. In that respect, the study presents an analysis of the organisational procedures related to tenure track decisions, the tensions created by hierarchical governance structures, and deans and department heads' sense-making of ambiguous situations for which no clear procedures or instructions exist. Tenure track committees represent new controlling bodies by which universities influence fields of research fields and the recruitment of academics. As a result, universities strengthen their position as stronger organisational actors, but at the same time they limit the freedom of departments to respond to field-specific needs.
\end{abstract}

Keywords: University organisations; governance; academic careers; tenure tracks

\section{Introduction}

Recruitment of academic staff and promotion are among the key instruments by which academic leaders in universities, such as rectors, deans and department heads, can affect the future direction

\footnotetext{
${ }^{*}$ Email: maria.pietila@helsinki.fi
} 
of research and teaching in academic units: recruiting and promoting staff with certain competencies directs the scope of potential research and teaching themes. While academic leaders' options for affecting the selection and promotion of academic staff are limited due to the organisational specificities of universities (Musselin 2007, 69-74) and the reliance on peer review in the evaluation of academic performance (Whitley 2008), leaders possess significant influence in determining the areas for which staff are recruited and choosing the criteria against which their performance is assessed.

Earlier research on academic careers indicates that in many countries, temporary and part-time contracts have partly replaced permanent full-time positions (e.g., Enders and de Weert 2004; Kimber 2003; Snyder and Dillow 2013, 309). Two groups of academic staff with differing working conditions can be recognised: 'the tenured core' and 'the tenuous periphery' (Kimber 2003; Enders and de Weert 2004; Nikunen 2012; Herbert and Tienari 2013).

Another stream of literature has reported on the expectations and career prospects of early career academics (e.g., Hakala 2009) and contract researchers (Hey 2001). According to Farnham (2009) and Huisman, de Weert, and Bartelse (2002) academic work has become less attractive in many European countries. Yet another group of studies has focused on the gender inequalities in academic employment (e.g., Probert 2005; Nikunen 2012).

Academic careers, as seen from the perspective of leaders, have so far been largely neglected in higher education studies. To address the gap, this study examines the purposes of a specific, new career system - tenure track, and how academic leaders in Finland use it. In addition to the attempts at the European Union level to make research career structures comparable and to improve the predictability of career in research in Europe (e.g., ESF 2009; Hynes et al. 2012), the Finnish career reforms are a result of some country- and university-specific needs.

By encouraging certain kinds of behaviour with appraisal and rewards, career systems may be used to serve organisation- and field-specific needs. Tenure tracks in Finland offer an interesting object of study, because the organisational autonomy of universities was increased from 2010. Within some constraints, universities can design their own career systems, reflecting a range of goals and applications in different academic units.

This study explores four themes: (1) the goals academic leaders perceive in the new career system, and (2) the administrative procedures by which these goals are pursued. When intended goals are pursued and translated into action, recipient interpretations of top-down initiatives affect the 
outcomes of change processes (Balogun and Johnson 2005). The instructions and procedures always provide leeway for active agents. Thus, the study also investigates (3) how deans and department heads make sense of ambiguous situations for which no clear procedures or instructions exist. As career systems are designed to work in unitary ways in heterogeneous university organisations, tensions between the needs of the 'complete' university organisation and individual academic units may arise. The analysis will focus on (4) possible tensions between the hierarchical levels in relation to the distribution of authority in selecting the positions and individuals for tenure track.

Theoretically the study builds on the literature that approaches universities as organisations. It examines the extent to which internal career paths contribute to making Finnish universities 'organisational actors' (e.g., Meier and Schimank 2010). Empirically the study draws on two Finnish case universities that launched tenure track systems in 2010. These universities have been the most active recruiters of staff into tenure track positions in Finland. Data for the study were drawn from interviews with academic and administrative leaders at several hierarchical levels, and from national and university documents.

\section{The university as an organisation and implications on career systems}

In the study, two analytical perspectives have been used as heuristics for understanding the interrelated patterns between governance structures and career systems in universities. These two perspectives can be contrasted in terms of centralisation / decentralisation of managerial selfgovernance, which refers to the internal hierarchies of university organisations (de Boer, Enders, and Schimank 2007, 139). The perspectives complement each other in studies of universities as employer organisations.

The first perspective portrays universities as inherently loosely coupled, decentralised organisations (Weick 1976; cf. Cohen, March and Olsen's notion of universities as organised anarchies 1972). Different disciplinary fields have divergent reward systems and labour market mechanisms with implications for academic careers and employment (Musselin 2010; Becher and Trowler 2001). In some national systems, actors other than the university as a collective organisation, such as individual professors, have traditionally had considerable influence on the career paths of academic staff (cf. Hüther and Krücken 2013, 5-7). Due to their internal heterogeneity, universities could be described as organisations with multiple strategic actors and with various operational environments. 
It is likely that department heads, for example, have partly conflicting expectations for a new career system.

The second perspective, challenging the traditional one, depicts universities turning into new organisational forms: universities are becoming more goal-oriented, accountable organisational actors, characterised by a unified strategy, central coordination and control, and a shared (constructed) identity (Brunsson and Sahlin-Andersson 2000; Meier and Schimank 2010; Krücken and Meier 2006; Musselin 2007; de Boer, Enders, and Leisyte 2007; Whitley 2008).

University leadership may have different incentives to centralise decision-making. From a logical point of view, Padgett (1980) recommends that in organised anarchies (such as universities) the president should rely on centralised decision-making by attending to personnel selection and structural design. According to Brunsson and Sahlin-Andersson's interpretative analysis (2000), recent public sector reforms have promoted a need to transform traditional entities, such as universities, into more 'complete organisations' (see also de Boer, Enders, and Leisyte 2007). From an institutional point of view, universities may be tempted to imitate the organisational forms of successful universities with centralised decision-making procedures (cf. DiMaggio and Powell 1983).

Brunsson and Sahlin-Andersson (2000) state that whereas public sector entities have typically lacked features of 'real' organisations, many of them are now trying to build an identity, characterised by autonomy, collective resources and clear boundaries between the organisation and its environment. Hierarchy is built with co-ordination and control, and rationality is constructed by setting objectives the fulfilment of which is measured. (Brunsson and Sahlin-Andersson 2000, 723729.)

In 'a soft bureaucracy' (Courpasson 2000), the power of certain groups, such as professional elites, may be reduced by hierarchical order and control (see also Kärreman and Alvesson 2004). Modern bureaucratic methods and structures include not only standardised organisational procedures and processes (cf. Mintzberg 1983), but also the use of new types of managerial indicators. Examples of this soft coercion (Courpasson 2000) in include performance evaluations, which aim to 'objectivate' the expected activities of academics.

The notion of portraying universities as organisational actors is reflected in the developments in the Finnish higher education sector. The Universities Act, which came into force from 2010, granted more financial power and autonomy to universities, 'in order to give the universities a stronger 
financial and administrative status [...]' (MEC 2009, 1). The reform encouraged universities to differentiate and to specify how they are special, making the reform an example of an external push towards identity-building (Brunsson and Sahlin-Andersson 2000, 726).

One of the aims of the reform was to allow universities 'to pursue their own human resources policies, geared to their specific features' (MEC 2009, 1). The reform made universities independent legal entities with employer status, stressing their autonomy as organisations (cf. Brunsson and Sahlin-Andersson 2000, 723-724). Prior to 2010, the ministry responsible for universities possessed significant authority in employment issues. Compared to centralised national systems (see Farnham 2009; Whitley 2008), Finnish universities are today comparatively autonomous. Autonomy entails each organisation having the option to decide on its career systems. In the negotiations between the university employers and trade unions concerning the conditions of work, the university employers are represented by a single collective association which has been bestowed with the bargaining rights for all Finnish universities.

However, there are constraints, which severely limit the universities' capacity to act as autonomous employers (Whitley 2008; Hüther and Krücken 2013). First, the 14 universities share one collective agreement.

Second, external research funding, which is not distributed by the state in the universities' block grants, is a major part of universities' R\&D funding (56.4\% in 2012; Statistics Finland 2012). Academics usually apply for external funds independently and with little reference to university strategy. The high proportion of project-based funding diminishes the autonomy of universities as organisations (Whitley 2008, 34-35).

Third, despite the high proportion of external funds, universities are still dependent on the state as their main provider of funds. The universities set annual targets in the performance negotiations with the responsible ministry. A ministerial decree also determines the educational responsibilities of universities, limiting the range of programmes a university can offer. As a result of these dependencies, Finnish universities as organisations are not completely free to make their own decisions (cf. Brunsson and Sahlin-Andersson 2000).

The fourth limitation for the exercise of leadership in universities is scholarly communities' primary role in governing the intellectual processes (Whitley 2008). Leaders' efforts to control academic careers are further constrained by the organisational specificities of universities, such as the low level of cooperation and coordination in teaching and research activities (Musselin 2007, 69-74). 


\section{Academic career systems in Finland}

As academic career trajectories and recruitment differ in different national systems (see Musselin 2010), this section briefly describes typical traits of academic recruitment and career phases in Finnish universities. It should be noted that the majority of academic recruitment and promotions in Finland are not related to tenure track.

Prior to the university reform, professors, lecturers, university teachers and assistants in Finnish universities had the status as the state's civil servants. Their nomination was regulated by legislation on nomination to the civil service. However, project researchers had the status of employees. In Finland, different legislation is applied to civil servants and employees. Professorial appointments were further regulated by their own specific law and a statute, which made career progress a regulated area at the national level.

Due to the Universities Act, the status of university personnel changed from being civil servants to being direct university employees. The Act identifies only one group of academic staff - professors, and continues to regulate their tasks and selection procedures to some extent. The internal regulations of each university may specify the selection procedures and qualification requirements.

There have long been attempts to systematise academic career paths in Finland. The research council of the Academy of Finland has promoted the need to develop professional academic careers (e.g., Oksanen, Lehvo, and Nuutinen 2003). More recently, a report identified four stages in the academic career path in Finnish universities and public research institutes (see MEC 2008). During the first stage, academics typically work on their doctoral dissertation on a fixed-term contract. After that, they may apply for vacant positions, such as post-doctoral positions, which are usually fixed-term (MEC 2008). Also, positions at the third stage, such as those of a lecturer, are based on an open call for applications. The report recommends that most of these positions should be permanent. The fourth stage includes professors, research directors and the like. Permanent professors are mainly recruited after an open call. In an exceptional case professorship may be filled by invitation. The report also mentions the possibility of having tenure tracks.

Because a large proportion of academic employment in Finland is fixed-term and promotions are usually based on vacancies, for an individual academic, career continuity has been occasional and unexpected. Junior researchers have found investing in an academic career to be risky (Hakala 2009), a problem also identified in other European countries. Tenure track, on the other hand, is based on explicit 'career steps', progressing from fixed-term appointments and the related qualification process to a tenured full professorship. The main difference between the tenure track 
and the traditional Finnish career system is the transparent opportunity to promote academics and to grant them tenure supported by administrative processes.

\section{Data and method}

Data collection began with pre-interviews in 2013 to provide background information on the topic and for the selection of cases. The interviewees represented national stakeholders in public administration, trade unions, and an employers' association. The representatives of public administration and the employers' association emphasised the universities' right to establish their own career systems, reflecting their role as stronger organisational actors. Interviewees also referred to increasing divides in universities' personnel policies.

Two universities were selected as study cases. These universities have made most tenure track recruitments in Finland. They launched the career system in 2010. University A was established in 2010, via the merger between three antecedent universities. It has about 4,700 staff and 20,000 students. This university consists of units spanning fields from science and technology to engineering, business, art and design. In the university's strategy document, establishment of the university is described as providing conditions for 'radical renewal and autonomous strategic investments'. The tenure track system is described as 'perhaps the most notable single reform implemented' in the university and an essential enabler in reaching strategic goals. As at March 2014, 135 people had been recruited either to tenure track positions or to tenured academic professorships. Of all professorial recruitment (including the previous 135 people and 21 practicebased fixed-term professors), some $68 \%$ were Finns and $76 \%$ men.

University B is an established, comprehensive university with units ranging from humanities and social sciences to natural sciences and medicine. University B has a staff of 8,400 people and 36,000 students. In December 2013, 35 staff had been recruited to tenure track positions. Of these, $66 \%$ were Finns and $68 \%$ men. At University A tenure track is the predominant recruitment channel for professors, whereas at University B it is a minor, parallel channel: most academic recruitment falls outside the tenure track. In the coming years, the aim is to expand its use.

Nineteen academic leaders (vice-rectors in charge of personnel policies, deans and department heads) and senior administrative leaders were interviewed. Department heads in particular were the target group since they are in an important position in advancing top-down changes in universities, enacting policies through active agency (cf. Balogun and Johnson 2005). To ensure at least partial coverage of the variety attached to academic careers in different fields, department heads from eight 
units in empirical and theoretical natural sciences and behavioural sciences/business were interviewed. To be able to distinguish the university-specific and field-specific factors, somewhat similar units in the two universities were selected.

Semi-structured interviews were conducted in 2014. They covered themes such as the broader context and the goals of the career system, organisational processes and guidelines, how the career system is put into practice, perceived problems, and areas to be developed. Because a tenure track had been in operation for only a short period, the interviews focused more on recruitment than promotions or tenure decisions. The duration of interviews ranged from 45 minutes to 2 hours. All interviews were taped and transcribed. The added quotes have been translated from Finnish to English. Additionally, documents on national objectives about academic careers, university strategies and process guidelines were collected and analysed.

Content analysis, which enables data to be reduced and summarised (Krippendorf 2004), was used to identify goals attached to the career system from the interview transcripts. Analysis on the responsibilities of the actors involved in the tenure track decisions is based mainly on university documents. The tensions in internal governance appeared as a repeated theme in the interviews. Thus, the findings about the tensions are presented separately.

Whereas explicit goals and the formal procedures are typically consciously chosen, people usually make sense of novel situations unconsciously, in an automatic mode (Gioia 1986). All interviewees had worked in academia before the launching of a tenure track. This enabled them to make sense of the new system by ascribing meaning to it through social interaction and reflection with past experiences in ambiguous situations for which no clear instructions existed or which left room for multiple interpretations (cf. Weick 1995; Rouleau and Balogun 2011). Section 5.3 focuses on the occasions that particularly call for sensemaking. However, it should be noted that all interviewees' interpretations of the goals and procedures involve sensemaking.

\section{Findings}

\subsection{Tenure track procedures}

According to the interviewees, tenure track systems in the case universities had been modelled according to foreign universities and modified to suit the context of a small country, the distinct national culture, and the specific needs of the universities. Tenure track as a long-term organisational commitment to individual academics was seen as a countermeasure to the short- 
sighted, project-based approach to recruitment: tenure track provided a more predictable career path for academics. Because of its nature as universities' internal career path, tenure track may result in a tighter social linkage between the employer and the employee (cf. Hüther and Krücken 2013).

In the case universities, tenure track decisions involve new actors when compared with traditional recruitment processes. The procedures in the key decisions are presented in Table 1. University A has also strengthened its human resource (HR) management function. HR professionals work in close collaboration with academic leaders and disseminate their experiences of the processes.

--Insert table 1 here--

At University A, tenure track recruitment calls may be targeted at assistant, associate, or full professor level, or at all levels in the same call. The academic positions are supplemented by practice-based professor nominations. The first contract as assistant professor is made for three to five years, followed by a second term as assistant professor for four years. The second step as associate professor is in most cases a permanent position, followed by permanent full professorship.

Common guidelines are applied in the recruitment and promotion processes. In decisions that determine the field of the positions and decisions that give tenure, decision-making is centralised to the rector. Deans are responsible for fixed-term recruitment.

New types of bodies - faculty- and university-level tenure track committees - control the recruitment, which with the strengthened centralised leadership will contribute to transforming University A into a comparatively strong organisational actor. The committees control the fairness and transparency of the selection and evaluation processes, but they have also intervened in cases where the proposed candidate has not fulfilled the university's recruitment criteria.

In a way tenure decisions are community decisions. We have to have a common idea about what [University A's] tenured professors should be like, even though there are field-specific characteristics.

At University B, tenure track begins with a contract for three to five years as assistant professor. This is followed by a second contract as associate professor for three to five years. Recruitment directly to the second stage is possible, but is used only in exceptions. The third stage is tenured professorship. Only people who have completed a doctoral degree in the past ten years are eligible to enter the track. 
Some tenure track procedures are centralised at University B, but with limited effects because of the lower amount of recruitment based on the tenure track path. The decision-making power in opening new positions has been centralised to the rector and the university-level tenure track committee. The committee has intervened in the proposals of the faculties when the field has been 'too narrowly defined' or if the grounds for the field have not been adequate in explaining 'how exactly they will further our strategic goals'. The committee also monitors the suitability of the proposed individual. These centralised procedures differ from other academic recruitment.

$[\ldots]$ it is the only $[\mathrm{HR}]$ system, where central administration is in dialogue with faculties. [...] the group [tenure track committee] here checks where they [the positions] will be opened. It has a kind of strategic importance that means we look at the allocation.

As a result of the centralised decision-making (Padgett 1980) and formal standardised HR procedures (Kärreman and Alvesson 2004), both the individual academics and also the decisionmakers in departments are dependent on the decisions of the rector and the tenure track committees.

\subsection{Goals of the tenure track system}

Reflecting perhaps the shared environment characterised by evaluations, rankings, and funding schemes, the rationales for adopting a new type of career system were similar at both case universities. The most significant goal was to aspire 'research and teaching excellence' by committing high-performing junior academics to the university and to an academic career. An internationally known career system was seen as serving this goal.

At University A, the changes in the career systems were tightly coupled with the merger process, whereas interviewees at University B emphasised the slow pace of changes in a university with a long history. The second, significant goal related to identity-building was to use the career system to allocate resources.

\subsubsection{Instrument for attracting juniors in a global academic labour market}

A central goal shared by leaders at all hierarchical levels was to use the tenure track to attract and commit junior-level academics to the university and to an academic career. The context of the career system was structured in an environment in which universities and individual units engage in global research competition. Academic staff and professors in particular were seen as key people in improving the quality of research and teaching, justifying emphasis on high-quality recruitments. Global competition was also seen as causing a need to attract more foreign candidates. Although the deans and department heads especially in 'hard sciences' described their fields as inherently international, global competition for the best individuals was portrayed as something new. 
International recruitment was compared to traditional Finnish academic recruitment, described as 'inbred' and 'old-world'.

In the interviews, the leaders considered the kinds of recruitment strategies they could employ in practice. Tenure track was presented as a new way to offer high-performing junior academics the possibility of entering an internationally attractive career path. Tenure track was also seen as improving junior academics' career prospects. The rationale for attracting juniors was not only the larger 'talent pool' of junior candidates, but also the practical difficulties to entice foreign, established academics to Finland, situated 'on the edge of Europe'.

We get more foreign applicants and such, when we get [to recruit] more junior people. The problem is that if we want to get top researchers here, at the time they have their own research groups, family and so on, it is very difficult to recruit them to Finland any more.

The global academic labour market presented as the broader context of the career system and juniors as the target implied new requirements for the universities as employers. These included the need for international marketing, globally competitive salaries, and a range of services to be provided to academics, such as start-up funding and mentoring.

\subsubsection{Instrument for resource allocation}

At University A, each time a tenured professor retires, the rector reconsiders the field. At University $\mathrm{B}$, the discretion for this is held by department heads in negotiation with the dean. At both universities, however, the rector and tenure track committees control the fields of new tenure track positions. The opportunities for reallocation make the career system a considerable control mechanism for the universities' leadership. Deans and department heads especially at University A saw the tenure track positions as the rector's tool for guiding the direction of research and teaching, because the positions are connected to the financial resources of faculties and departments. According to some department heads, this may promote strategies of 'safe choices' and impede interdisciplinary initiatives that cross unit boundaries.

At both universities, departments suggest fields for new positions. The proposals had reflected the needs of the departments, arguments ranging from forthcoming retirements to ideas on new scholarly areas and interdisciplinary initiatives. Many of the specific areas of the positions were based on the departments' current research areas, educational needs, or areas that needed to be developed because of their societal importance or potential in academic terms.

The department heads and deans emphasised the departments as organisational units and the candidates as part of the work community. The official recruitment criteria for the tenure track 
emphasised traditional notions of individual performance and merit, such as publications and experience in teaching. In the interviews, recruitment was presented as being a highly complex process involving multiple actors and in effect requiring higher-than-usual notions of individual performance and merit (cf. Brink and Benschop 2011). The applied criteria included notions about the national need for certain research and teaching themes, the current composition of staff, and strategic visions of departments. This emphasises tenure track recruitment as a set of strategic decisions on resource allocation for departments.

After [seeing the external reviews] I think we as department have freer hands to use our own arguments about what we want of that group [of candidates]: what kind of strategy we want to implement with this recruitment and overall what kind of a profile we want.

Several deans and department heads stated that the relative significance of external reviews in recruitment had decreased, whereas more weight was now given either to situation- and individualspecific discretion or to detailed recruitment criteria set at the faculty level. This possibility was connected to the universities' new employer status.

The way I have perceived these tenure track recruitment instances is that they are no longer appointments to public office. They are recruitment situations in which the one who does the recruiting has the freedom to act accordingly to his/her own view.

\subsection{Findings about sensemaking}

For deans and department heads, tenure track was something new that required them to make sense of it, entailing questions about how it differed from traditional career paths. Analysing the sensemaking processes of deans and department heads as active agents and shapers of top-down change initiatives is important, because their interpretations may influence the career system's outcomes (cf. Rouleau and Balogun 2011; Floyd and Wooldridge 2000).

In the interviews, the department heads deliberated about the processes and incidents for which no clear instructions had been created. One characteristic of the career system which aroused contradictory responses was the expected organisational commitment to the tenure track academic on the one hand, and concern for 'tying the hands of the department too early', on the other. Referring to past experiences, some department heads remarked upon the Finnish tradition of having a large number of fixed-term contracts and the considerable leeway this provided for departments. Some leaders, such as the dean quoted below, adopted a long-term investment approach:

[...] I have a strong idea that I want to support and help the person so that (s)he can blossom and achieve something for our common good. And that (s)he will have energy to work the rest of his/her life in the university. 
In contrast, some department heads and deans especially those in the hard sciences voiced a need not only for promoting internal careers, but also to recruit more staff at assistant professor level and to be able to discontinue some of the contracts. By referring to the practices in the US, focus on assistant professors and discontinuations was seen as an essential part of 'genuine' tenure tracks. However, in practice good availability of more senior academics had in many cases led to recruiting associate professors. Also, discontinuation was seen as difficult to put into practice in the Finnish context with a low number of equivalent workplaces, low mobility, and high employment protection.

[...] we have quite a powerful, strong culture concerning what a permanent contract is. It's a good question whether we even really have a chance not to grant tenure. I think the system should be developed so that we could take risks especially at the assistant phase. Provided that we'd have a chance not to grant tenure without it being a catastrophe for any party.

According to logic of appropriateness (March and Olsen 1989), acting against internalised, tacitly understood rules may be deemed illegitimate by the actors in the field. Thus, discontinuing contracts may be both risky and an unattractive alternative for the university as employer.

\subsection{Tensions in centralised procedures}

The department heads and deans described some of the tensions that the new hierarchical procedures had created within the university. These tensions were voiced especially by department heads, whereas deans generally expressed more approval of hierarchical governance. The contradictions identified are related to the collision between simultaneous quests for the centralisation and decentralisation of self-governance in universities (de Boer, Enders, and Schimank 2007).

In universities, departments or equivalent units represent academic fields. Differing labour market mechanisms characterise the fields, and each department has particular research and teaching orientations. The hierarchical procedures related to the career system invoked reactions about unit autonomy (e.g., where the relevant expertise for recruitment lies), practical problems caused by bureaucratic processes, experiences of alienation and distrust due to loss of decision-making power, and questions whether the research-oriented career path suffice for all fields.

First, resistance to centralised procedures was manifested most strongly in questions about the function of the tenure track committees, described as 'guillotine committees'. While some deans and department heads also appreciated their role in guaranteeing the uniformity and parity of recruitment and promotions within the university, external interference in the definition of research positions and recruitment decisions was generally disapproved. Interference was resisted by 
principled arguments emphasising the autonomy and expertise of the units in selecting sub-fields and applying field-specific recruitment criteria.

Second, centralised procedures caused slowness and stiffness in the processes. At University B where there are alternatives for how professors can be recruited, department heads felt it might even be 'simpler' to recruit a professor than an assistant professor. The bureaucratic modes of organising, such as allocating tenure track positions only at certain times of the year at University A, were questioned in an academic environment 'where big things emerge spontaneously', as a department head stated.

Leaders in the hard sciences, in particular, felt that the involvement of multiple actors in tenure track decisions put them in a disadvantaged position, because the potential recruits sought jobs from many organisations.

For example now we have a process where it seems that there's a short list of six people and half of them, the foreign applicants, have received offers from elsewhere during the process.

Third, some department heads interpreted the hierarchical governance structures as indications of distrust and control. The committees were seen as depriving decision-making power from departments and faculties, who nevertheless remain accountable for the units' performance. Due to the centralised governance, one department head felt he hardly had any influence on the content of tenure track positions, causing experiences of alienation.

I find somehow that it's a thing which is out of our or out of my reach, a thing which I have no influence on, so it's not worth spending a lot of time on it. And because the decision-makers have very clear opinions, some of which I disagree - and because I know these opinions - I try to focus on other things.

Fourth, the centrally defined research-oriented career steps were seen as inadequate for faculties with a large number of teaching-oriented staff and for practically oriented academic fields which have primarily national value. Some deans and department heads found it somewhat difficult to adjust different fields into the structures of the tenure track.

Tenure track represents an internal career path which attaches academics closer to their employing organisation (cf. Hüther and Krücken 2013). However, the creation of separate classes of staff with differing indicators for recognition and prerequisites for career progression may generate a gap between research- and teaching-intensive positions and between tenure track staff and contract researchers (cf. Kimber 2003; Nikunen 2012; Herbert and Tienari 2013). These gaps are increased when universities invest in tenure track academics as the university's core group with individualised remuneration and targeted events. 


\section{Discussion and conclusions}

This study examined the interrelated patterns of governance structures and career systems in a university context by analysing the goals attached to new tenure track systems, the related decisionmaking procedures and the tensions these procedures create in organisations with multiple semiautonomous units and fields with different career patterns and reward systems. In addition, attention was given to the sensemaking processes of department heads and deans who are shapers of topdown change initiatives (Rouleau and Balogun 2011; Floyd and Wooldridge 2000; Balogun and Johnson 2005). Department heads and deans act as mediators between the top leadership and the work community.

In the case universities, tenure track systems have two common goals. First, they are used to attract high-performing junior researchers globally. This goal highlights how two central, interlinked discourses frame the leaders' attempts to develop academic career paths: the quest for research excellence and (to a lesser extent) teaching excellence and internationalisation. The urge to launch the career system underpins a construction of Finnish universities competing in the international research market, which entails a need to compete in the global labour market. This aim in the context of a small, remote country in Europe was shared by leaders at all organisational levels. It may be stated that Finnish universities have entered the international 'research game' (cf. Lucas 2006).

The second mutual goal, using tenure track positions to allocate resources, is related to attempts to build distinct profiles with 'special competence' (Brunsson and Sahlin-Andersson 2000, 726; Meier and Schimank 2010). This is supported by recruitment criteria that exceed traditional notions of individual 'excellence', and include assessments about the strategic visions of departments (cf. Brink and Benschop 2011).

Research inspired by Weick's (1995) notions of sensemaking and enactment emphasises people as agents producing the contexts in which they operate. Based on the findings, the constructed environments of the leaders at different hierarchical levels differ. Top leaders rationalised the need for hierarchical recruitment with pressures present in their operational environment. Their constructions may be influenced by broader global policies, which support the transformation of universities towards stronger organisational actorhood (see Krücken, Blümel, and Kloke 2009). The centralised governance structures, regulated career paths and standardised levels of performance (cf. de Boer, Enders, and Schimank 2007; Kärreman and Alvesson 2004), however, collide with the interests of departments. The environments of the basic units are characterised by unique research 
endeavours and teaching needs, justifying the need for more decentralised governance structures and autonomy. It seems problematic to integrate the two views.

The new position of universities as direct employers, and their ability to generate their own employment practices are indicators of the transformation of Finnish universities into stronger organisational actors (cf., e.g., Brunsson and Sahlin-Andersson 2000; Krücken and Meier 2006; Whitley 2008). New bodies - tenure track committees - are examples of a new type of control mechanism and attempts to centralise decision-making in recruitment and promotion in a soft bureaucracy (Courpasson 2000). With the help of centralised committees, universities standardise and strengthen career processes, recruitment and promotion criteria. However, the work processes and performance of academics cannot easily be standardised (cf. Musselin 2007). The interviewees uniformly resisted mechanistic performance appraisal. This provides some leeway to departments and individual academics.

The organisational autonomy of Finnish universities increased from 2010. Indeed, the leaders were conscious of the employer status. The constructed implications of this status and autonomy, however, also differed between the actors at the different hierarchical levels. Vice-rectors and senior administrative leaders interpreted the new employer status as a chance to adopt a more uniform recruitment policy within the university. For department heads, autonomy and being a formal employer meant an opportunity to strengthen the department's perspective in recruitment. The above-described tensions arise when both the university as a collective entity and the individual departments aim to construct an identity endowed with autonomy and special ways of working (cf. Brunsson and Sahlin-Andersson 2000, 723-726). As senior leaders attempt to advance policies that handle the university as a complete entity, they may at the same time narrow down the freedom of action necessary to advance department-specific personnel and academic goals.

This study contributes to research on university governance and to research on the tensions in hierarchical governance structures when changes are translated into action (cf. Balogun and Johnson 2005). The study analysed empirical cases from a small national system, which has recently undergone changes in the authority relations between universities and the state, and within universities. As a result of these changes, Finnish universities have new opportunities to adopt different kinds of governance structures.

The findings indicate notable differences between the case universities in the initiation of tenure track procedures. Universities, in which the senior leadership has been granted significant power to influence the allocation of resources, may well be developing into more 'complete organisations'. 
This may be backed up with top-down selection of deans and department heads. On the other hand, universities with more decentralised, collegially oriented governance structures, remain largely 'loosely coupled'. However, these implications are not black and white. Despite the line organisation structure and the ability of senior leaders to affect key personnel selection (cf. Padgett 1980), professorial recruitment cannot be described as a simple top-down structure: multiple actors, including external peer reviewers, are involved in the decisions.

The study also contributes to research on academic careers. When studying academic careers, the leaders' perspective is important, but an insufficient perspective. The special features of academic work and career progression entail other actors being involved in career decisions. In addition to the members of the international scholarly community, who in the Finnish case still significantly influence academic recruitment, the actors include research funders, such as research councils, foundations, and private companies, which follow their own missions. The actors form a complex network with sometimes conflicting preferences. In order to understand the factors that affect academic careers, more research on the complexity of the network of actors is needed.

\section{Notes on contributor}

Maria Pietilä is doctoral student at the University of Helsinki, Department of Political and Economic Studies.

\section{Acknowledgments}

Various colleagues have helpfully commented different drafts of the paper. I would especially like to thank Turo Virtanen, Pertti Ahonen, James Fairweather, Minna Nikunen, $9^{\text {th }}$ EUREDOCS Conference participants, and EGOS 2014 'Universities in Unsettled Times: Effects of Evaluations, Accreditations and Rankings' sub-theme participants for comments and ideas.

\section{References}

Balogun, J., and G. Johnson. 2005. "From Intended Strategies to Unintended Outcomes: The Impact of Change Recipient Sensemaking.” Organization Studies 26 (11): 1573-1601.

Becher, T., and P.R. Trowler. 2001. Academic Tribes and Territories: Intellectual Enquiry and the Culture of Disciplines. Buckingham: Society for Research into Higher Education, Open University Press.

de Boer, H., J. Enders, and L. Leisyte. 2007. "Public Sector Reforms in Dutch Higher Education: The Organizational Transformation of the University." Public Administration 85 (1): 27-46. 
de Boer, H., J. Enders, and U. Schimank. 2007. "On the Way towards New Public

Management? The Governance of University Systems in England, the Netherlands, Austria, and Germany." In New Forms of Governance in Research Organizations. Disciplinary Approaches, Interfaces and Integration, edited by D. Jansen, 137-152. Dordrecht: Springer.

van den Brink, M., and Y. Benschop. 2011. "Gender Practices in the Construction of Academic Excellence: Sheep with Five Legs.” Organization 19 (4): 507-524.

Brunsson, N., and K. Sahlin-Andersson. 2000. "Constructing Organizations: The Example of Public Sector Reform.” Organization Studies 21 (4): 721-746.

Cohen, M.D., J.G. March, and J.P. Olsen. 1972. "A Garbage Can Model of Organizational Choice." Administrative Science Quarterly 17 (1): 1-25.

Courpasson, D. 2000. "Managerial Strategies of Domination. Power in Soft Bureaucracies."

Organization Studies 21 (1): 141-161.

DiMaggio, P., and W. Powell. 1983. "The Iron Cage Revisited: Institutional Isomorphism and Collective Rationality in Organizational Fields.” American Sociological Review 48 (2): 147-160.

Enders, J., and E. de Weert. 2004. "The International Attractiveness of the Academic Workplace in Europe - Synopsis Report." In The International Attractiveness of the Academic Workplace in Europe, edited by J. Enders and E. de Weert, 7-27. Frankfurt am Main: GEW.

ESF 2009. Research Careers in Europe. Landscape and Horizons. A Report by the ESF Member Organisation Forum on Research Careers. European Science Foundation.

Farnham, D. 2009. "Employment Relations in Europe: A Comparative and Critical Review." In The Changing Face of Academic Life: Analytical and Comparative Perspectives, edited by J. Enders, and E. de Weert, 195-217. Issues in Higher Education. New York: Palgrave Macmillan.

Floyd, S.W., and B. Wooldridge. 2000. Building Strategy from the Middle. London: Sage.

Gioia, D.A. 1986. "Symbols, scripts and sensemaking: Creating meaning in the organizational experience.” In The Thinking Organization, edited by H.P. Jr. Sims, and D.A. Gioia, 49-74. San Francisco, CA: Jossey Bass.

Hakala, J. 2009. "The Future of the Academic Calling? Junior Researchers in the Entrepreneurial University." Higher Education 57 (2): 173-190.

Herbert, A., and J. Tienari. 2013. "Transplanting Tenure and the (Re)construction of Academic Freedoms.” Studies in Higher Education 38 (2): 157-173.

Hey, V. 2001. "The Construction of Academic Time: Sub/contracting Academic Labour in Research." Journal of Education Policy 16 (1): 67-84.

Huisman, J., E. de Weert, and J. Bartelse. 2002."Academic Careers from a European Perspective.” The Journal of Higher Education 73 (1): 141-160. 
Hynes, M., L. Ackers, S. Avveduto, E. Basri, E. Boudard, L.C. Castro, J. Langer, et al. 2012. Excellence, Equality and Entrepreneurialism. Building Sustainable Research Careers in the European Research Area. Final report drafted for the European Commission - DG for Research and Innovation. 20 July 2012.

Hüther, O., and G. Krücken. 2013. "Hierarchy and Power: A Conceptual Analysis with Particular Reference to New Public Management Reforms in German Universities.” European Journal of Higher Education 3 (4): 307-323.

Kimber, M. 2003. “The Tenured 'Core' and the Tenuous 'Periphery': The Casualisation of Academic Work in Australian Universities." Journal of Higher Education Policy and Management 25 (1): 41-50.

Krippendorf, K. 2004. Content Analysis. An Introduction to its Methodology. Thousand Oaks, California: Sage.

Krücken, G., and U. Meier. 2006. "Turning the University into an Organizational Actor." In Globalization and Organization: World Society and Organizational Change, edited by G.S. Drori, J.W. Meyer, and W. Hwang, 241-257. Oxford; New York: Oxford University Press.

Krücken, G., A. Blümel, and K. Kloke. 2009. "Towards Organizational Actorhood of Universities: Occupational and Organizational Change within German University Administrations." Deutsches Forschungsinstitut für Öffentliche Verwaltung, Speyer. Discussion papers 48.

Kärreman, D., and M. Alvesson. 2004. "Cages in Tandem: Management Control, Social Identity, and Identification in a Knowledge-Intensive Firm." Organization 11 (1): 149-175.

Lucas, L. 2006. The Research Game in Academic Life. Maidenhead, England; New York: Open University Press.

March, J.G. and J.P. Olsen. 1989. Rediscovering Institutions. New York: Free Press.

MEC. 2009. Proposal for the New Universities Act in Brief. 20.2.2009. Ministry of Education and Culture, Finland.

http://www.okm.fi/export/sites/default/OPM/Koulutus/koulutuspolitiikka/Hankkeet/Yliopistolaitoks en_uudistaminen/liitteet/HE_yolaki_eng_20.2.2009.pdf.

MEC. 2008. The four-stage research career model. Reports of the Ministry of Education, Finland.

Meier, F., and U. Schimank. 2010. "Mission Now Possible. Profile Building and Leadership in German Universities." In Reconfiguring Knowledge Production: Changing Authority Relationships in the Sciences and Their Consequences for Intellectual Innovation, edited by R. Whitley, J. Gläser, and L. Engwall, 211-238. New York: Oxford University Press.

Mintzberg, H. 1983. Structure in Fives: Designing Effective Organizations. Englewood Cliffs, NJ: Prentice Hall.

Musselin, C. 2010. The Market for Academics. New York: Routledge. 
Musselin, C. 2007. “Are Universities Specific Organisations?” In Towards a Multiversity? Universities Between Global Trends and National Traditions, edited by G. Krücken, A. Kosmützky, and M. Torka, 63-84. Bielefeld: Transcript.

Nikunen, M. 2012. "Changing University Work, Freedom, Flexibility and Family." Studies in Higher Education 37 (6): 713-729.

Oksanen, T., A. Lehvo, and A. Nuutinen 2003. Suomeen tieteen tila ja taso [The State of Scientific Research in Finland]. Publications of the Academy of Finland 9/2003.

Padgett, J.F. 1980. "Managing Garbage Can Hierarchies.” Administrative Science Quarterly 25 (4): 583-604.

Probert, B. 2005. “'I just Couldn't Fit It In': Gender and Unequal Outcomes in Academic Careers." Gender, Work \& Organization 12 (1): 50-72.

Rouleau, L., and J. Balogun. 2011. "Middle Managers, Strategic Sensemaking, and Discursive Competence." Journal of Management Studies 48 (5): 953-983.

Snyder, T.D., and S.A. Dillow. 2013. Digest of Education Statistics 2012 (NCES 2014-015). National Center for Education Statistics, Institute of Education Sciences, U.S. Department of Education. Washington, DC.

Statistics Finland. 2012. Official Statistics of Finland. Research and development [e-publication]. Helsinki: Statistics Finland [referred: 9.6.2014]. Access method: http://www.tilastokeskus.fi/til/tkke/index_en.html.

Weick, K.E. 1995. Sensemaking in Organizations. Thousand Oaks: Sage.

Weick, K.E. 1976. "Educational Organizations as Loosely Coupled Systems.” Administrative Science Quarterly 21 (1): 1-19.

Whitley, R. 2008. "Universities as Strategic Actors: Limitations and Variations." In The university in the market, edited by L. Engwall and D. Weaire, 23-37. London: Portland Press.

\begin{tabular}{|l|l|l|}
\hline & University A & University B \\
\hline $\begin{array}{l}\text { Decisions about the field } \\
\text { of the position }\end{array}$ & $\begin{array}{l}\text { Rector allocates the position to } \\
\text { faculty / department based on } \\
\text { negotiations with dean }\end{array}$ & $\begin{array}{l}\text { Proposal from faculty, tenure track } \\
\text { committee provides a statement to } \\
\text { rector, rector makes the decision }\end{array}$ \\
\hline $\begin{array}{l}\text { Decisions about } \\
\text { recruitment criteria }\end{array}$ & $\begin{array}{l}\text { University-level criteria, specified } \\
\text { faculty- and department-level } \\
\text { criteria }\end{array}$ & $\begin{array}{l}\text { University-level criteria, faculties and } \\
\text { departments may have specified } \\
\text { criteria }\end{array}$ \\
\hline Decisions about the & a) Assistant professors: Proposal & Proposal from department's selection \\
\hline
\end{tabular}




\begin{tabular}{|c|c|c|}
\hline recruited candidate & $\begin{array}{l}\text { from department's selection } \\
\text { committee (incl. interviews, external } \\
\text { reviews / confidential letters of } \\
\text { reference, and teaching competence } \\
\text { evaluation). Dean makes the decision } \\
\text { after consulting the faculty-level } \\
\text { tenure track committee. b) Associate } \\
\text { and full professors: Proposal from } \\
\text { department's selection committee } \\
\text { (based on interviews, external } \\
\text { reviews, teaching competence } \\
\text { evaluation and service evaluation) to } \\
\text { dean who hears the faculty-level } \\
\text { tenure track committee. Non- } \\
\text { tenured associate professors: dean } \\
\text { makes the decision. Tenured } \\
\text { professors: dean presents the } \\
\text { proposal to rector. University-level } \\
\text { tenure track committee gives a } \\
\text { recommendation to rector, rector } \\
\text { makes the decision. }\end{array}$ & $\begin{array}{l}\text { committee (incl. external reviews and } \\
\text { teaching competence evaluation). } \\
\text { Dean and department head provide a } \\
\text { statement if not part of the } \\
\text { committee. University-level tenure } \\
\text { track committee makes a comment to } \\
\text { rector, rector makes the decision. }\end{array}$ \\
\hline $\begin{array}{l}\text { Promotion and tenure } \\
\text { decisions }\end{array}$ & $\begin{array}{l}\text { 1st assistant professorship to } 2 \text { nd } \\
\text { assistant professorship: department } \\
\text { head makes a proposal to dean } \\
\text { whether to grant a second term, } \\
\text { dean makes the decision. Tenure } \\
\text { and promotion reviews: department } \\
\text { head makes a proposal to dean to } \\
\text { initiate the review process. } \\
\text { Department's selection committee } \\
\text { (incl. external reviews, teaching } \\
\text { competence evaluation and service } \\
\text { evaluation) makes a proposal to } \\
\text { dean. After hearing the faculty-level } \\
\text { tenure track committee, dean } \\
\text { presents the candidate to rector if } \\
\text { (s)he is in favour of granting tenure. } \\
\text { After hearing the university-level }\end{array}$ & $\begin{array}{l}\text { Assistant to associate professor: Same } \\
\text { department committee as in the first } \\
\text { recruitment, possibility to use external } \\
\text { reviewers. Department head / dean } \\
\text { provides a statement. If needed, } \\
\text { university-level tenure track } \\
\text { committee provides a statement. } \\
\text { Rector makes the decision. Associate } \\
\text { professorship to full professorship: } \\
\text { Same department committee (incl. } \\
\text { external reviews, teaching } \\
\text { competence evaluation and service } \\
\text { competence evaluation). a) If the } \\
\text { committee expresses that tenure } \\
\text { should not be granted, proposal is sent } \\
\text { to rector. Department head and dean } \\
\text { give a statement. If rector agrees, (s)he }\end{array}$ \\
\hline
\end{tabular}




\begin{tabular}{|l|l|l|}
\hline & $\begin{array}{l}\text { tenure track committee, rector } \\
\text { makes the decision. }\end{array}$ & $\begin{array}{l}\text { terminates the process. If rector thinks } \\
\text { there are grounds for granting tenure, } \\
(\text { s)he hears university-level tenure } \\
\text { track committee and may hear the } \\
\text { different parties. (S)he sends } \\
\text { documents to chancellor who makes } \\
\text { the decision. b) If the selection } \\
\text { committee is in support of tenure, } \\
\text { dean provides a proposal and his / her } \\
\text { statement to chancellor. Chancellor } \\
\text { makes the decision. }\end{array}$ \\
\hline
\end{tabular}

Table 1. Central procedures and actors in tenure track recruitment at University A and University B. 